\title{
Educational Values in Human Rights Treaties: UN, European, and African International Law
}

\section{Pablo Meix-Cereceda ${ }^{1}$}

Published online: 21 July 2020

(C) Springer Nature B.V. 2020

\begin{abstract}
While human rights treaties provide a formidable set of principles on education and values, domestic Courts often tend to adjudicate claims in terms of local arguments for or against each particular educational practice. This article explores how international human rights law could inspire the interpretation of domestic law and educational practice, without neglecting specific cultural aspects. Firstly, the article reviews the sociological debate on values in education and shows its importance for the legal discussion. Secondly, some critical contestations of international cultural human rights are outlined, as well as certain arguments to justify the importance of this model. The study of international law follows: the UN, the European Court of Human Rights, and three relevant African Charters, as well as every reference to education made by the African Commission on Human and Peoples' Rights and by the African Court is examined. Lastly, a comparative section reveals a certain cultural commonality inspired by the UN treaties, but also reflects some cultural and institutional differences between the European and the African regional systems.
\end{abstract}

Keywords Educational values · Human rights education $\cdot$ Cultural rights $\cdot$ Best interest of the child · African Charter on the Rights and Welfare of the Child · African Charter on Democracy, Elections, and Governance

\section{Values in Education: the Complexity of Interests and the Law}

It can be argued that the social behavior of the individual is highly influenced by the desire to achieve certain goals. These goals are influenced by the specific set of values broadly driving a society, which they in turn shape over time, at least to a certain extent. This set of common values lastly comes to influence the drafting of constitutions and

Pablo Meix-Cereceda

pablo.meix@uclm.es

1 Faculties of Labor Relations and Law / Facultades de Relaciones Laborales y Derecho, University of Castilla-La Mancha, Albacete campus, Plaza de la Universidad, 1., 02071 Albacete, Spain 
laws within a state. As the German philosopher and law scholar Häberle $(1981,211)$ wrote, "educational aims are an essential content of cultural constitutional law." However, this does not mean that laws necessarily base on a unanimous understanding of certain values, but more often on the conception of a majority of citizens. Taking one step further, when a significant number of states decide to establish an international system of human rights, these values are discussed by their representatives and eventually become part of a convention or a charter in a wording that is acceptable to the high contracting parties. If the system is successful, it will in turn infuse its lifeblood into the domestic education system by providing certain standards based on problematic cases.

Considering the task of schools, they seek to instill certain values that eventually will allow their learners to play a successful part in society (Dewey 1916, 271). Whether stressing the acquisition of applied technical knowledge or expressly proclaiming the need to develop virtue in learners, modern education systems strive to create ideas of the socially valuable and the socially unacceptable. A brief recollection of the sociological debate on education may provide a useful context in order to understand the relationship between educational goals and social values.

According to Martín Criado (2010, 22 and 30-32), functionalist sociologists like Durkheim or Talcott Parsons broadly argue that the function of the school is to instill the common values necessary for social cohesion. Social cohesion would be the essential aim, and school action would be legitimate in order to instill values that work toward such aim. The values of solidarity, tolerance, diversity, and compassion and others may be considered here.

On the other hand, critical sociologists like Bourdieu and Passeron (1970) denounced in their essential work on education that the values instilled by the education system rather reflect the interests of the dominant classes. School systems would be designed to maintain a specific social stratification, to use Lenski's classical notion (1966). ${ }^{1}$

It could be argued that all of these authors agree - if only implicitly — at least on one point: the aims of the educational system determine the values that it seeks to instill. As Glenn has written $(2017,29)$ :

...whether intentionally or not, every school tends to educate as well as to instruct; inevitably it immerses its pupils in a school culture that conveys countless messages about what qualities and behaviors are admirable.

But despite their undeniable importance, both lines of thinking tend to reduce the complexity of interests at stake in education, as Martín Criado has pointed out (2010, 69-75 and 85-91). Indeed, many different actors exercise their influence in the education system: individuals (the learners themselves, parents, teachers, owners of private schools), groups (teacher unions, political parties, private companies, churches) and, prominently, public bodies such as Administrations and Legislatures.

Concerning the role of laws and international treaties in this framework, they certainly are one of the preconditions that will expand, or limit, the possibilities of

\footnotetext{
${ }^{1}$ G. Lenski's major work Power and Privilege. A Theory of Social Stratification spread the use of the term "stratification" in sociology. Nevertheless, John Dewey had used the notion already in 1916 (2015, p. 101).
} 
educational action in schools. Botha $(2019,185)$ has advocated the importance of international law as a reference and inspiration for interpreting domestic law and practice on educational matters involving human rights. With regard to national legal systems, Du Plessis (2019, 49 and 2020) has pointed out the exemplarity of the Preamble of the South African National Education Policy Act 27 of 1996 when it proclaims that "the education system must be transformed into one which serves the needs and interests and upholds the fundamental rights of all the people of South Africa."

Nevertheless, the concrete result in each learner's education will vary according to a complex interaction of all the aforementioned factors. Using a sculptural metaphor, constitutions and international human rights treaties would provide a sediment of values to the educational clay. However, this clay will be modeled, to a greater or a lesser extent, by the hands of all the aforementioned actors.

The starting point of this piece is that education always implies the transmission of certain values which, nevertheless, are sometimes in a tension with each other or even contradict each other. Therefore, the absorption of values in each learner's case is not easily controlled by one single force but is the result of many influences. The child's own freedom will in all probability play a major role in how these values intertwine and weigh on their moral decisions.

\section{The Importance of International Human Rights Law: Contestations and Reasons}

The notion of human rights culture has been contested as reflecting a Eurocentric philosophy of the individual. Indeed, as Stoppioni $(2020,2)$ has recently reminded, "the fundamental problem of the European conception of human rights would be to focus exclusively on the individual and to forget the group". A harsher critique considers that “"human rights' are, as such, a false ideological universality, which masks and legitimizes a concrete politics of Western imperialism, military interventions and neocolonialism" (Žižek 2005). These arguments criticize what Bonfiglio (2018) has called "human rights colonialism," which the same author has sought to overcome by proposing an intercultural theory of human rights.

From an African perspective, Justice Mokgoro (1998, 8), of the Constitutional Court of South Africa, has claimed the proximity between human rights and the traditional values of ubuntu, while acknowledging that the communal dimension of ubuntu could enrich the interpretation of western law. In this regard, she mentions in particular the following ideas:

- The original conception of law perceived not as a tool for personal defense, but as an opportunity given to all to survive under the protection of the order of the communal entity

- Communalism which emphasizes group solidarity and interests generally, and all rules which sustain it, as opposed to individual interests, with its likely utility in building a sense of national unity among South Africans

- The conciliatory character of the adjudication process which aims to restore peace and harmony between members rather than the adversarial approach which 
emphasizes retribution and seems repressive. The lawsuit is viewed as a quarrel between community members and not as a conflict. The importance of group solidarity requires restoration of peace between them

- The importance of public ritual and ceremony in the communication of information within the group

- The idea that law, experienced by an individual within the group, is bound to individual duty as opposed to individual rights or entitlement. Closely related is the notion of sacrifice for group interests and group solidarity so central to ubuntu(ism)

- The importance of sacrifice for every advantage or benefit, which has significant implicants for reciprocity and caring within the communal entity

Even if they were not written apropos of education, these reflections seem especially relevant to the debate on educational values, in particular with respect to which values the school system ought to promote and the related problem of conflict and restorative justice in schools.

The abovementioned critical views, however, cannot undermine the importance of international protection. As will be discussed especially in "African Union: Commonality and Specificities", regional international bodies have both the necessary independence from states and the ability to deliver a relevant view in terms of idiosyncratic proximity. In addition, the lack of adequate solutions in certain domestic cases would prove the necessity of international protection for at least certain categories of subjects. This seems of particular relevance in the case of children, arguably the most vulnerable subjects of human rights. Some examples from Southern African domestic courts may be helpful to illustrate the latter claim.

In some cases, national courts have selected international rulings that may be isolated in a court's body of case law or not applied as a meaningful precedent by the international court itself. For instance, in the Arundel School case ${ }^{2}$ the Constitutional Court of Zimbabwe ruled against the application of certain pupils who had been obliged to attend school prayer by the new headmistress. The pupils' parents, who were Jehova's Witnesses, had expressly declared their faith upon the application for admission of their children, and the children had been attending the school before the arrival of the new headmistress. Despite the fact that the application had been filed by the parents, the Constitutional Court expressly declared the right to expel the pupils, which the school had not yet carried out. Even more surprising, however, was the fact that the Constitutional Court based on the European Court's reasoning in the case of Valsamis of 1996, which has been changed in more recent rulings on similar claims, such as the cases of Folgerø (2007), Zengin (2007), or Yalçın (2014) (see below, "European Court of Human Rights" for details).

In other cases, national courts simply refrain from using international law as a source of inspiration, even when it could reinforce the authority of their own rulings. In this regard, the generally protective Constitutional Court of South Africa rarely integrates arguments from international law when ruling on matters concerning children and education. In the case of the Juma Musjid Primary School, ${ }^{3}$ the principle of the child's

\footnotetext{
${ }^{2}$ Makani v Arundel School (CCZ 7/16, Const. Application No. CCZ 17/15) [2018] ZWCC 7 (29 June 2016).

${ }^{3}$ Governing Body of the Juma Musjid Primary School \& Others $v$ Essay N.O. and Others (CCT 29/10) [2011] ZACC 13; 2011 (8) BCLR 761 (CC).
} 
best interest was only discussed in terms of national constitutional law in spite of the importance that international law has in this field (see below "Full Development of the Human Personality and Best Interest of the Child"). In this case, an eviction order was sought by the owner of the land where a school was based. The Constitutional Court mentioned certain international treaties and soft law on the right to education, ${ }^{4}$ and even a US Supreme Court ruling, ${ }^{5}$ but no international decisions by African or UN bodies were considered. The Constitutional Court held that the KwaZulu-Natal High Court had failed to take account of the interests of the learners and, instead, had simply "privileged the right to property over the learners' right to a basic education" (para 71). Nevertheless, the Court considered that the children had been successfully accommodated by other schools and therefore ruled for the owners and granted the order of eviction.

Another important case from South Africa concerned the pregnancy policies adopted by several schools. In the Welkom and Harmony High Schools case, ${ }^{6}$ the Constitutional Court declared these policies unconstitutional for being contrary to a number of rights including non-discrimination, the right to education, and the respect of the child's best interest. ${ }^{7}$ As will be discussed below, the African Commission on Human and Peoples' Rights has often sought to convince states and schools of the need to ensure school attendance of girls in general, and very especially in the case of pregnancy. Nevertheless, and despite a specific allegation by one of the parties, the Constitutional Court did not mention any rule of international law in its judgment.

Other situations and cultural practices may deeply affect the full development of children and their right to education, as demonstrated by the ACHPR's appeals against genital mutilation, child labor, child marriage, and other forms of denial of the right to schooling, as will be discussed in the following sections of this article.

While it is difficult to conceive international remedies as a valid instance for reviewing every domestic ruling, they are certainly useful for both denouncing and inspiring educational and legal practice. State authorities - but also individualsshould take notice of the problems detected by international bodies and, with the help of available or new domestic remedies, gradually work toward the improvement of such problems in daily practice.

In this regard, the article seeks to provide a comprehensive view of the educational values advanced in three international human rights jurisdictions: the UN, the European Court of Human Rights, and the African instruments. Part of the elements protected by these jurisdictions is shared by the other systems, but each of them has developed certain specificities. Concerning the latter, an effort has been made to examine every allusion to education made by the African Court on Human and Peoples' Rights (hereinafter African Court) and the African Commission on Human and Peoples' Rights (hereinafter ACHPR). Lastly, some comparative considerations on the three systems will be outlined.

\footnotetext{
${ }^{4}$ Ibid., paras 40 and 41.

${ }^{5}$ Olmstead et al. v. United States [1928] USSC 133; 277 U.S. 438 (1928).

${ }^{6}$ Head of Department, Department of Education, Free State Province v Welkom High School and Another; Head of Department, Department of Education, Free State Province v Harmony High School and Another (CCT 103/12) [2013] ZACC 25; 2013 (9) BCLR 989 (CC); 2014 (2) SA 228 (CC) (10 July 2013).

${ }^{7}$ Ibid. paras $112-116$.
} 


\section{United Nations' Human Rights Instruments}

The Universal Declaration of Human Rights (hereinafter UDHR) ${ }^{8}$ includes a remarkable set of educational values. They have been further developed by some of the major human rights treaties sponsored by the UN. Four kinds of values seem relevant in this regard.

\section{Full Development of the Human Personality and Best Interest of the Child}

The "full development of the human personality" principle is expressly mentioned in art 26 para 2 of the UDHR and has been adopted as the main goal of education by many treaties and even constitutions. In order to grasp the meaning of this principle, it may be worth exploring some interesting variations across different international treaties and declarations.

In 1959, 11 years after the UDHR, the Declaration of the Rights of the Child ${ }^{9}$ would state that education "will promote (the child's) general culture, and enable him, on a basis of equal opportunity, to develop his abilities, his individual judgement" (principle 7).

This declaration acknowledged the relationship between a person's awareness of the world that surrounds them ("general culture") and the development of their personality both in terms of their talents ("abilities") and their moral sense ("individual judgment"). Thirty years later, the Convention on the Rights of the Child (CRC) would rephrase and widen these ideas stating the following:

(...) the education of the child shall be directed to: (a) The development of the child's personality, talents and mental and physical abilities to their fullest potential (...). ${ }^{10}$

The main purpose thus became the development of talents and abilities, both mental and physical, as part of the more complex concept of the "child's personality."

The 1959 Declaration, on the other hand, included what is nowadays considered the main goal that should guide not only education but generally any measure concerning children. Indeed, after the abovementioned statement, principle 7 went on as follows:

The best interests of the child shall be the guiding principle of those responsible for his education and guidance; that responsibility lies in the first place with his parents.

Full development of the personality and a child's best interest thus appear clearly connected if we consider the UDHR and the Declaration of the Rights of the Child jointly. This connection may be useful in order to construe the principle of best interest in some difficult cases. Indeed, when the 1959 Declaration referred to the best interests

\footnotetext{
${ }^{8}$ Adopted 10 December 1948 UNGA Res 217 A(III) (UDHR).

${ }^{9}$ Declaration of the Rights of the Child (Proclaimed by the General Assembly, resolution $1386(X I V)$, A/RES/ 14/1386, 20 November 1959) (DRC).

${ }^{10}$ Convention on the Rights of the Child (adopted on 20 November 1989, entered into force 2 September 1990) 1577 UNTS 3 (CRC) art 29 para 1.
} 
of the child as "the guiding principle of those responsible for his education", it also specified that this responsibility lies "in the first place with his parents". This phrase certainly means that parents are, prima facie, considered the fittest to decide what that interest may be.

Nevertheless, there may be some cases where parents may not be able or willing to distinguish between their own interest or belief, on one hand, and the child's best interest on the other: child labor, ${ }^{11}$ underage marriage, ${ }^{12}$ female genital mutilation (girls' circumcision), ${ }^{13}$ or recruitment into militias ${ }^{14}$ are only some of the most dramatic examples. In these cases, it may be difficult to justify an intervention of public authorities based solely on the principle of "the child's best interest," as parents might claim that international law enables them "in the first place" to determine that interest in each case.

Nevertheless, a joint interpretation of this principle and the full development of the child's personality may prove useful in this regard. An individual's personality may keep developing through all stages of life, which means that full development is almost an ideal, or, from a legal perspective, a principle permanently subject to the possibility of progression. This seems even clearer in the case of a child. Therefore, if a decision from the parents may pose a clear threat to the child's future development, intervention from public authorities would then be justified insofar as necessary (and not any further) to safeguard the child's future possibilities of personal development.

Another interesting variation can be found in the International Covenant on Economic Social and Cultural Rights ${ }^{15}$ :

(...) education shall be directed to the full development of the human personality and the sense of its dignity (...)

Human dignity has been considered as a single human right ${ }^{16}$ and as a theoretical foundation of the entire legal system (Solozábal Echavarría 1994, 2489 and García Guerrero 2014, 199) and even of the state (Häberle 2004, 319). From a practical perspective, however, if a person's human rights are violated or even threatened, that person may in all probability not lead a decent life. This paragraph from the ICESCR hence reminds that the right to education is almost literally a "key right," which raises in children and adults awareness of their own dignity, and eventually allows them to fight for their rights by any means acceptable in their society. From an economic

\footnotetext{
11 The African Commission for Human and Peoples' Rights (ACHPR) sent on 23 March 2018 a letter of urgent appeal to the authorities of Uganda "Concerning alleged child labour in extractive industries, particularly gold mining."

${ }^{12}$ Association pour le progrès et la défense des droits des femmes maliennes (APDF) and the Institute for Human Rights and Development in Africa (IHRDA) v Republic of Mali African Court of Human and Peoples' Rights 11 May 2018, especially paras 71-78. In addition, the ACHPR's 40th activity report (of 2016) acknowledged that "In January 2016, child marriage was declared illegal in Zimbabwe by the Constitutional Court" (para 27.a.ix).

13 The ACHPR's 34th activity report (2013) found positive developments for human rights in this regard in Senegal and the ACHPR's 36th activity report (of 2014) in four states of the Sudan.

${ }^{14}$ The ACHPR's 34th activity report (2013), para 21, denounced the situation in the Republic of Congo.

${ }^{15}$ International Covenant on Economic, Social and Cultural Rights (adopted 16 December 1966, entered into force 3 January 1976) 993 UNTS 3 (ICESCR) art 13 para 1.

${ }^{16}$ So, the ACHPR in Purohit v. Gam., Comm. 241/2001, 16th ACHPR AAR Annex VII (2002-2003) para 57.
} 
perspective, education would allow individuals from poorer origins to improve their situation - which is often described with the "social lift" metaphor. ${ }^{17}$ These ideas can be summarized in the words of the Committee on Economic, Social and Cultural Rights (CESCR), which conceives education as "an empowerment right". 18

One last important aspect that UN-promoted treaties often link to full individual development is the "strengthening of respect for human rights and fundamental freedoms". This phrase is used to describe one of the two basic aims of education according to art 26 para 2 of the UDHR (the other one being the full development of the human personality). The phrase between quotes has thus come to represent, in international legal terms, the effort of the society to create a conscience in the child. In this regard, an early but powerful wording can be found in the 1924 Geneva Declaration of the Rights of the Child:

The child must be brought up in the consciousness that its talents must be devoted to the service of fellow men.

It is however the Convention on the Rights of the Child that enshrines the richest catalog of educational and developmental aims. From the perspective of this paper, there are at least two interesting references in its text. Firstly, the Convention's Preamble reminds that the "child should be fully prepared to live an individual life in society". Secondly, and elaborating on this idea, art 29 para 1 even claims that "the education of the child shall be directed to: (...) (d) The preparation of the child for responsible life in a free society (...)".

Two different aspects should be underlined here. On the one hand, this sentence reminds that the child is to be educated in order to become a healthy adult, which prevents exploitation and generally any abusive treatment, considering that a child is not yet an adult.

But, on the other hand, the fact that the child will eventually develop into an adult also stresses the need to gradually promote a certain responsibility and maturity. Therefore, education should prepare a child to live autonomously in a free society. Preparing a child for freedom also means preparing it for responsibility, for making its own rules and taking its own decisions as a useful member of the society, to quote principle 7 of the 1959 UN Declaration of the Rights of the Child.

This link between individual development and respect for human rights paves the way for the second of the aims mentioned in the general international law.

\section{Promoting Understanding, Tolerance, and Peace}

The second aim of education would be clearly political. With different variations, most of the texts include understanding, tolerance, and peace among their political aims for education. A good example can be found in art 26 para 2 of the UDHR, according to which, education "shall promote understanding, tolerance and friendship among all nations, racial or religious groups, and shall further the activities of the United Nations for the maintenance of peace".

\footnotetext{
${ }^{17}$ The expression is attributed to Pitirim Sorokin (Jonsson 2016, 3).

${ }^{18}$ CESCR, General Comment no. 13, para 1.
} 
The promotion and maintenance of peace has been the most important principle of international law at least since the establishment of the United Nations in 1945 (White 1997, 3). It was enshrined in the Charter of the United Nations ${ }^{19}$ as the maintenance of "international peace and security".

The reference to "understanding, tolerance and friendship among all nations, racial or religious groups" would enable the primary goal of maintaining peace. Nevertheless, it can be seen as a more ambitious purpose, too. In this respect, it seems that the UDHR expects, or even promotes, the emergence of a global society, which in turn would be expected to achieve much more than preventing its peoples from going to war against each other.

Over 40 years later, the Convention on the Rights of the Child would repeat and widen the ideals of the Universal Declaration in this respect. The reference to nations and racial and religious groups was then completed with the more flexible "friendship among all peoples, ethnic, national and religious groups and persons of indigenous origin."

Moreover, the equality of sexes also joined the previous understanding, peace and tolerance.

It is probably needless to remind that between the 1948 UDHR and the 1989 CRC, the International Convention on the Elimination of All Forms of Racial Discrimination $^{20}$ and the Convention on the Elimination of All Forms of Discrimination against Women ${ }^{21}$ had been adopted, putting these problems on the international agenda.

International law thus acknowledges the importance that children are made aware of the society's complexity as part of their growth and education process, and of the need to respect and equally treat every individual regardless of their social circumstances. Indeed, the relationship between human rights and education can be conceived in dialectic terms. In this regard, promoting human rights in education by celebrating difference $^{22}$ could in turn make education a force for social cohesion and understanding. The school system could enhance the child's awareness of different cultural approaches to sensitive or controversial matters, bearing in mind the age and maturity of the learners. For instance, discussion could be encouraged on the role of religion in society, the importance of art, the relationship between freedom of speech and political correctness, environmental conscience, sex or drugs, to name but a few of these controversial matters. A number of authors have underlined these ideas by naming human rights education a human right itself (Alfredsson 2001, 273; Benedek 2007, 1).

Despite the claim for universality of human rights and the importance of promoting mutual understanding, the social circumstances surrounding a child are also important for education, as the third aim from the UN treaties conveys.

\footnotetext{
${ }^{19}$ Charter of the United Nations (adopted 26 June 1945, entered into force 24 October 1945) (UN Charter) art 1 para 1.

${ }^{20}$ International Convention on the Elimination of All Forms of Racial Discrimination (adopted 7 March 1966, entered into force 4 January 1969) 660 UNTS 1.

${ }^{21}$ Convention on the Elimination of All Forms of Discrimination against Women (adopted 18 December 1979, entered into force 3 September 1981) 1249 UNTS 1.

${ }^{22}$ Mittler $(2000,10)$ has developed a model of inclusive education. In his words, "inclusion implies a radical reform of the school in terms of curriculum, assessment, pedagogy and grouping of pupils. It is based on a value system that welcomes and celebrates diversity arising from gender, nationality, race, language of origin, social background, level of educational achievement or disability" (emphasis added.)
} 


\section{Cultural Background: Language and Convictions}

The third kind of values that are found in most declarations and treaties have to do with what sociologists would call the "meso" or middle level of societies. International law thus reveals an awareness of the importance that intermediate bodies (groups) have in a person's life. The family - despite its diminishing size in many societies - is considered the main channel for the flow of values from the groups that make a society to the child. Language, cultural values, and moral and religious references, as well as many other traditions, are gradually absorbed by the child in an environment of such high affectivity as the family.

All of these ideas could be summarized as the protection of cultural pluralism in education. Indeed, even a treaty as sparing in educational matters as the International Covenant on Civil and Political Rights includes a reference to religious and moral education, if only to proclaim the right of parents to ensure that such education is delivered "in conformity with their own convictions". ${ }^{23}$

Nevertheless, it is very difficult to construe this principle as a right to ensure that any education involving moral or even religious contents can only be attempted in conformity with the convictions of families. The reasons would be twofold. On the one hand, the scope of contents potentially affected by moral or religious views is so wide that it would be practically impossible to carry out an institutionalized education. Thus, equal access to formal education ${ }^{24}$ and other principles that are part of the right to education would be made void. On the other hand, the aforementioned principles of the full development of the human personality and the best interest of the child justify that certain contents of public interest be addressed in a non-indoctrinatory manner, even against parental wishes. Sex education has frequently been a controversial matter, ${ }^{25}$ but teaching in certain languages in some parts of the world can be just as disputed. ${ }^{26}$

However, it is the CRC that best captures the essence behind the need to ensure pluralism in education. In its Preamble, the States Parties acknowledge "Taking due account of the importance of the traditions and cultural values of each people for the protection and harmonious development of the child".

Also, when discussing placement of the child outside its original family, art 20 para 3 mandates that " (...) due regard shall be paid to the desirability of continuity in a child's upbringing and to the child's ethnic, religious, cultural and linguistic background."

Moreover, art 29 para 3.c places the following values among the aims of education:

\footnotetext{
${ }^{23}$ ICCPR, art 18 para 4. Also in ICESCR, art 13 para 3.

${ }^{24}$ Case of Mürsel Eren v Turkey European Court of Human Rights 7 February 2006 (ECLI:CE:ECHR:2006:0207JUD006085600).

${ }^{25}$ Case of Kjeldsen, Busk Madsen and Pedersen v Denmark European Court of Human Rights (Grand Chamber) 7 December 1976, (ECLI:CE:ECHR:1976:1207JUD000509571) and case of Jiménez Alonso and Jimenez Merino v. Spain European Court of Human Rights (decision) 25 May 2000 (ECLI:CE:ECHR:2000:0525DEC005118899).

${ }^{26}$ Northern Cyprus: Case of Cyprus v Turkey European Court of Human Rights (Grand Chamber) 10 May 2001 (ECLI:CE:ECHR:2001:0510JUD002578194). Turkey: Case of Irfan Temel and others v Turkey European Court of Human Rights 3 March 2009 (ECLI:CE:ECHR:2009:0303JUD003645802). Transdniestria: Case of Catan and others $v$ the Republic of Moldova and Russia European Court of Human Rights (Grand Chamber) 19 October 2012 (ECLI:CE:ECHR:2012:1019JUD004337004).
} 
The development of respect for the child's parents, his or her own cultural identity, language and values, for the national values of the country in which the child is living, the country from which he or she may originate, and for civilizations different from his or her own (emphasis added).

However, the importance of all these cultural values does not prevent art 14 para 1 from proclaiming " (...) the right of the child to freedom of thought, conscience and religion".

We may inquire about the purpose of stressing cultural specificity in international human rights treaties. This does not seem an appropriate occasion for developing all the complexity of the tension between the universality of human rights and their implementation in different cultural environments. But it may be useful to point out a few considerations on the matter, in particular concerning the topic of this article. Cultural traditions may have a great value in collective terms, for example as a way of preserving different valid approaches to the world and to mankind. According to the African Court,

culture should be construed in its widest sense encompassing the total way of life of a particular group, including the group's languages, symbols such as dressing codes and the manner the group constructs shelters; engages in certain economic activities, produces items for survival; rituals such as the group's particular way of dealing with problems and practicing spiritual ceremonies; identification and veneration of its own heroes or models and shared values of its members which reflect its distinctive character and personality. ${ }^{27}$

However, this does not appear as the main argument to ponder here. When discussing child education and values, other considerations seem to take precedence. The rights of parents to instill certain values and, generally, the protection of specific groups and their traditions find a strong justification in the need of a certain psychological stability of the child, a feeling of safety which is crucial for a healthy development of the young who will, over time, become adults. Childhood, once again, is not only protected on account of its intrinsic value - which it clearly has, as the right to the child's freedom of conscience underlines - but also because it is the seed of tomorrow's adults that will shape society.

\section{Environmental Conscience}

A fourth kind of values, still not very common in international law on education, refers to a growing concern in other domains of international law. Art 29 para 1 of CRC shows this concern in the following terms:

[States Parties agree that the education of the child shall be directed to (...)]

e. The development of respect for the natural environment.

\footnotetext{
${ }^{27}$ Case of the African Commission on Human and Peoples Rights $v$ Kenya (006/2012) [2017] African Court 28; (26 May 2017) para 179.
} 
Given the overwhelming scientific analyses that place human activity at the origin of global warming, and of air, water, and land pollution among many other environmental hazards, the fact that this fundamental value is mentioned as a goal of education in only one of the major conventions on human rights can only be received with surprise. Nevertheless, it is a perfectly valid obligation under international law, enshrined in a treaty that is binding for 196 States Parties, three more than the Member States of the United Nations. The USA seems to be the only state not to have ratified or adhered to this Convention (of which, however, it is a signatory).

\section{European Court of Human Rights}

The European Court of Human Rights (hereinafter ECtHR) has produced approximately 40 judgments and decisions on educational matters. Concerning values in education, the Court's rulings stem from the second sentence of article 2 of the first additional Protocol $^{28}$ to the Convention. ${ }^{29}$ This sentence reads as follows:

In the exercise of any functions which it assumes in relation to education and to teaching, the State shall respect the right of parents to ensure such education and teaching in conformity with their own religious and philosophical convictions.

In spite of this rather open wording, the ECtHR has nevertheless managed to develop a rich case law. It is not possible to examine all of these rulings in detail or to discuss some of the ECtHR's excesses. I will therefore limit the analysis to a broad summary of three principles before focusing on how they apply to Human Rights Education, given its relevance for the discussion.

Firstly, the ECtHR has displayed a rather extensive conception of the states' "margin of appreciation". This is especially true in matters of religious symbols, either personal (Swiss teachers, ${ }^{30}$ Turkish students, ${ }^{31}$ or French learners ${ }^{32}$ ) or institutional. Among the latter, the Italian "crucifix case" 33 is widely known, but earlier rulings dealt with religious freedom and national celebrations in Greek schools. $^{34}$

Secondly, the ECtHR has frequently applied the "best interest of the child" doctrine whenever this interest could be endangered by parental religious or philosophical

\footnotetext{
${ }^{28}$ Protocol to the Convention for the Protection of Human Rights and Fundamental Freedoms (entered into force 18 May 1954 ETS No.009).

${ }^{29}$ Convention for the Protection of Human Rights and Fundamental Freedoms (European Convention on Human Rights, as amended) (entered into force 3 September 1953) (ECHR).

${ }^{30}$ Case of Dahlab v. Switzerland European Court of Human Rights (decision) 15 February 2001 (ECLI:CE:ECHR:2001:0215DEC004239398).

${ }^{31}$ Case of Leyla Şahin v. Turkey European Court of Human Rights (Grand Chamber) 10 November 2005 (ECLI:CE:ECHR:2005:1110JUD004477498).

32 Among others, the case of Kervanci v. France European Court of Human Rights (in French) 4 December 2008 (ECLI:CE:ECHR:2008:1204JUD003164504) and the case of Dogru v. France European Court of Human Rights 4 December 2008 (ECLI:CE:ECHR:2008:1204JUD002705805).

${ }^{33}$ Case of Lautsi v. Italy European Court of Human Rights (Grand Chamber) 18 March 2011 ECLI:CE:ECHR:2011:0318JUD003081406.

${ }^{34}$ Case of Valsamis and case of Efstratiou, both of the European Court of Human Rights 18 December 1996 (ECLI:CE:ECHR:1996:1218JUD002178793) and (ECLI:CE:ECHR:1996:1218JUD002409594).
} 
convictions: the abovementioned cases of Kjeldsen ${ }^{35}$ and Jiménez Alonso, ${ }^{36}$ or the decision in the Konrad $v$ Germany case, ${ }^{37}$ are some of the most prominent examples on sex education (the first two) and compulsory schooling (the third one). The best interest of the child principle, however, has occasionally been subordinated to a state's margin of appreciation whenever there has been a conflict between the two. For instance, a conflict between the best interest of the child and the French principle of secularism, or the Italian defense of the crucifix, or the Greek celebration of the national day. Most of the cases mentioned in the previous paragraph exemplify this statement.

A third group of cases has developed from 2007. These rulings deal with indoctrination in the classroom. They address the instilment of certain religious values through specific ritual practices in compulsory classes for underage learners ${ }^{38}$ or a disproportionate attention to certain religious doctrines and a practical neglect of others. ${ }^{39}$ The ECtHR has upheld the applicants in all such cases.

\section{Human Rights Education}

Human Rights Education (HRE) was mentioned above as one of the key instruments for education to perform as an empowerment right (see above "Promoting Understanding, Tolerance, and Peace"). It can be provided as an autonomous subject or transversally through different subjects, or even as non-formal education. ${ }^{40}$ In some cases, however, a vivid controversy has been prompted by the introduction of a specific subject in the school system.

This was the case of Spain after 2006, when the new subject on "Education for Citizenship and Human Rights" was denounced and legally challenged by the political opposition and the Catholic Church. The subject was deemed constitutional in a number of rulings by both the Supreme Court ${ }^{41}$ and the Constitutional Court, ${ }^{42}$ but the central claim of the opponents to the bill deserves some consideration nevertheless. According to this claim, the curriculum of the subject would have been indoctrinating because it reflected an intent of the state to instill certain moral values. In the opinion of the applicants, such an objective would be the prevalent responsibility of the families and therefore the state should refrain from interfering with it.

\footnotetext{
35 See above n. 25.

36 Ibid.

${ }^{37}$ Case of Konrad v Germany European Court of Human Rights (decision) 11 September 2006 (ECLI:CE:ECHR:2006:0911DEC003550403).

${ }^{38}$ Case of Folgerø and others v Norway European Court of Human Rights (Grand Chamber) 29 June 2007 (ECLI:CE:ECHR:2007:0629JUD001547202).

${ }^{39}$ Case of Hasan and Eylem Zengin European Court of Human Rights 9 October 2007 (ECLI:CE:ECHR:2007:1009JUD000144804) and case of Mansur Yalçın and others v Turkey European Court of Human Rights 16 September 2014 (ECLI:CE:ECHR:2014:0916JUD002116311).

${ }^{40}$ The ACHPR, for instance, has repeatedly stressed the importance of both formal and non-formal human rights education (5th ordinary session, held in Benghazi on 3-14 April 1989).

${ }^{41}$ The Supreme Court (Administrative Chamber) delivered three rulings on 11 February 2009: judgments nos. 340/2009 (ECLI:ES:TS:2009:340); 341/2009 (ECLI:ES:TS:2009:341); and 342/2009 (ECLI:ES:TS:2009:342).

42 The Constitutional Court dismissed three applications for conscientious objection against the subject: judgment no. 28/2014 of 24 February 2014 (ECLI:ES:TC:2014:28); judgment no. 41/2014 of 10 April 2014 (ECLI:ES:TC:2014:41) and judgment no. 57/2014 of 5 May 2014 (ECLI:ES:TC:2014:57).
} 
While the highest domestic courts held that certain values could be legitimately taught by the school system, the case never reached the ECtHR and hence the question may remain whether the Spanish subject would have been sanctioned by the European Court or, on the contrary, whether it would have been declared indoctrinating. However, the ECtHR has delivered a number of rulings on the legitimacy of teaching values within the education system. In this respect, the abovementioned cases from Norway and Turkey are useful precedents. ${ }^{43}$ As explained, parts of the curricula in these cases were considered indoctrinating on account of the prevalence granted to certain religious beliefs and rites. Interestingly, however, the ECtHR made it clear that the teaching of values in school entails a valuable opportunity for young people to appreciate and respect difference and even to experience the commonality of many moral principles that underlie various systems of beliefs. ${ }^{44}$ Concerning the Spanish case, and given that no specific aspects of the curriculum had been challenged before the national courts, it seems arguable that the ECtHR would have upheld the decision to introduce the Education for Citizenship and Human Rights subject.

The misgivings of the applicants concerning the Spanish subject stem perhaps from the understanding that state values essentially equal a particular government's values. Nonetheless, this is precisely the boundary between acceptable HRE and unlawful and indoctrinating ideological reeducation. Openness and debate should be part of HRE, and teachers should refrain from conveying their own views where the discussion goes beyond the common principles underlying society. This can certainly be a thin line and may not necessarily avoid the risk of complaints by specific parents, but a teacher or educator who adopts a meticulous and open approach would in all probability be in accordance with the view of the ECtHR.

\section{African Union: Commonality and Specificities}

Human rights treaties fostered by the Organization of African Unity (OAU) and its successor the African Union (AU) include certain interesting obligations from the perspective of values in education. In addition, the African Commission on Human and Peoples' Rights (hereinafter the ACHPR) has provided, and continues to do so, valuable resolutions and other soft law instruments as well as case-based decisions through its communications procedure. The ACHPR's activity reports are also an invaluable source of information to keep track of both "positive developments" and "areas of concern" for human rights in the continent.

\footnotetext{
${ }^{43}$ See n. 38 and n. 39.

${ }^{44}$ Case of Folgerø, cit. (see n. 38), para 88: "The intention was that the school should not be an arena for preaching or missionary activities but a meeting place for different religious and philosophical convictions where pupils could gain knowledge about their respective thoughts and traditions (...). In the view of the Court, these intentions were clearly consonant with the principles of pluralism and objectivity embodied in Article 2 of Protocol No. 1". And para 89: “(...) From the drafting history it emerges that the idea was that the aim of avoiding sectarianism and fostering intercultural dialogue and understanding could be better achieved with an arrangement, such as here, bringing pupils together within the framework of one joint subject (...) Moreover (...) the second sentence of Article 2 of Protocol No. 1 does not embody any right for parents that their child be kept ignorant about religion and philosophy in their education." A similar reasoning in paras 58 $\& 59$ of the Zengin case (see n. 39).
} 
The key document of African instruments on human rights is the African Charter on Human and Peoples' Rights (hereinafter, African Charter). Provisions on education, however, appear scarce in the African Charter, and there is only one specific reference on art 17 para 1: "Every individual shall have the right to education". Apparently, and when compared to UN provisions on education's goals and values, there is no reference to such values in the basic African instrument. Nevertheless, it should be noted that article 17 also refers to free participation in the community's cultural life as a right of every individual (para 2 ) and to the duty of the state to promote and protect "morals and traditional values recognized by the community" (para 3). This systematic proximity induces the consideration that education, participation in the community's cultural life, and the protection of moral and traditional (non-colonial) values are deeply connected in the African Charter's spirit. This interpretation will be further discussed in "African Morals, Traditional Values and Cultures, and Other Specific Political Principles" below.

In contrast to the African Charter on Human and Peoples' Rights, the African Charter on the Rights and Welfare of the Child ${ }^{45}$ displays a rich wording when dealing with educational values. This treaty has been so far ratified by 49 states and signed by another five. Only one state (Morocco) has done neither. ${ }^{46}$

In addition, some provisions of the African Charter on Democracy, Elections, and Governance will be discussed. ${ }^{47} \mathrm{Up}$ to the present, 34 states have become parties to it and fifteen others have become signatories. Six states, however, have accomplished neither yet (Botswana, Egypt, Eritrea, Libya, Morocco, and Tanzania). ${ }^{48}$

Let us now focus on the values that should guide education according to these three Charters.

\section{Development of the Child's Personality}

Although this fundamental aim does not differ in substance from the one set in the UDHR and the core international human rights instruments, African instruments have included certain elaborations that deserve specific consideration. Art 11 para 2 of the African Child Charter includes a phrase that is almost identical to another in the Convention on the Rights of the Child, which seems a reasonable outcome given the proximity of their respective adoptions (1989 for the CRC and 1990 for the ACC). The first of the goals mentioned reads as follows:

the promotion and development of the child's personality, talents and mental and physical abilities to their fullest potential.

\footnotetext{
$\overline{45}$ African Charter on the Rights and Welfare of the Child (adopted 11 July 1990, entered into force 29 November 1999) (African Child Charter or ACC).

${ }^{46}$ List of states updated on 28 June 2019 (last deposit by São Tomé and Príncipe on 27 June 2019).

47 African Charter on Democracy, Elections and Governance (adopted 30 January 2007, entered into force 15 February 2012) (ACDEG).

${ }^{48}$ List of states updated on 28 June 2019 (last deposit by São Tomé and Príncipe on 27 June 2019).
} 
However, and beyond this initial commonality with UN-fostered treaties, the African conception seems particularly concerned about the importance of education - and leisure (Udombana 2006 ${ }^{49}$ ) - for individual self-development in general and for promoting awareness of the own rights in particular.

Not by chance, in 2013, the ACHPR identified among its "areas of concern" the fact that "many children are not in school despite the provision of free and compulsory education in some State Parties, due to socio-cultural and political considerations, among others ${ }^{50}$;

Moreover, the ACHPR has included as a "positive development," among other measures taken to protect the rights of children, "the introduction of school feeding programs in South Africa to encourage parents to send their children to school". 51

As well as the fact that certain states "(...) have put in place educational systems that are specifically tailored to suit the mobile lifestyles of their indigenous populations/ communities (Namibia) (...)". 52

Despite these achievements, certain "socio-cultural" patterns seem to hinder some specific groups, in particular women and girls. Many examples can be found in the ACHPR's activity reports. Among these, in 2012, the Special Rapporteur on the Rights of Women in Africa informed the Commission that "The situation of women in the rural areas remains dire, and in the area of education, the problem of girls' access to education despite the progress made by some countries" (sic). ${ }^{53}$

More recently, the ACHPR intensified its appeal in order to denounce the "continuing discriminations and practices against women and girls, including the exclusion of pregnant girls from the education system and refusing them to take public examinations, which violates their right to education and serves to perpetuate other discriminations against them". 54

In this regard, the ACHPR has also addressed letters of urgent appeal to certain governments that seemed to embrace these convictions, as revealed by "the statement made by the Tanzanian authorities on 22 June 2017 to the effect that pregnant girls and teen mothers would no longer be allowed to attend school and continue their education". 55

Fully aware of these hindrances, one of the most recent legal instruments in African human rights, the African Charter on Democracy, Elections, and Governance, directed its State Parties "to provide free and compulsory basic education to all, especially girls, rural inhabitants, minorities, people with disabilities and other marginalized social groups", 56 as well as to ensure "the literacy of citizens above compulsory school age, particularly women, rural inhabitants, minorities, people with disabilities, and other marginalized social groups". 57

\footnotetext{
${ }^{49}$ Art 12 of the ACC refers to the right "to engage in play and recreational activities appropriate to the age of the child." See also N.J. Udombana (2006, 190).

${ }^{50}$ ACHPR, 34th activity report (2013), para 21.vii. Emphasis added.

${ }^{51}$ ACHPR, 36th activity report (2014), p. 11, para v. Emphasis added.

52 ACHPR, 30th activity report (2011), para 251.

${ }^{53}$ ACHPR, combined 32nd and 33rd activity reports (2012), para 251.

${ }^{54}$ ACHPR, 38th activity report (2015), para 41.B.vi. Emphasis added.

55 ACHPR, 43rd activity report (2017).

${ }^{56}$ ACDEG art 43 para 1.

${ }^{57}$ ACDEG art 43 para 2.
} 
Thus, an instrument apparently intended for political rights mandates the establishment of a free and compulsory education system and grants special attention to disadvantaged groups. Nevertheless, it must not surprise that a Charter on Democracy, Elections, and Governance refers to education in such detail. To quote John Dewey's classic book Democracy and Education, "the realization of a form of social life in which interests are mutually interpenetrating, and where progress, or readjustment, is an important consideration, makes a democratic community more interested than other communities have cause to be in deliberate and systematic education" (Dewey 1916, 100-101). More recently, and from the perspective another regional system for the protection of human rights, the Inter-American Court of Human Rights considered education as the "epitome of indivisibility and interdependence of all human rights". 58 Despite the political importance of education, however, complaints brought before the ACHPR through the communications procedure have often addressed insufficiency of funding or facilities, as well as a lack of dedicated teaching staff. ${ }^{59}$

So far, it may be concluded that African instruments on human rights consider the very accessibility to school education as a key element for the first value that should guide education: the full development of the child's personality. Therefore, great interest is placed in countering social and cultural convictions that limit such accessibility.

\section{Respect for Human Rights, Fundamental Freedoms, and Democratic Principles}

Despite its clear connection with the previous aim, the importance that different African instruments attach to this matter recommends devoting a specific subsection to its discussion.

After the development of the child's personality, the African Child Charter considers that education should be directed to:

fostering respect for human rights and fundamental freedoms with particular reference to those set out in the provisions of various African instruments on human and peoples' rights and international human rights declarations and conventions $^{60}$

The concept of education as an "empowerment right," already mentioned above, has been received in the African instruments on human rights. Indeed, this idea was already present in the African Charter despite the scarcity of its provisions on education. ${ }^{61}$

As such empowerment right, education helps the child - and future adult - to take informed decisions (thus increasing individual freedom) and live in better conditions (improving a certain equality and fostering solidarity). One specific example of better

\footnotetext{
${ }_{58}$ Gonzales Lluy and others $v$ Ecuador Inter-American Court of Human Rights Series C No 298 (1 September 2015) para 234. See also Hevia Rivas (2008, 143 and 2010, 29).

${ }^{59}$ Socio Economic Rights and Accountability Project v. Nig., Comm. 300/2005, 25th ACHPR AAR Annex (May-Nov 2008). The complaint was declared inadmissible due to lack of proof concerning the exhaustion of domestic remedies.

${ }^{60} \mathrm{ACC}$, art 11 para 2.b.

${ }^{61}$ African Charter, art 25: "State Parties (...) shall have the duty to promote and ensure through teaching, education and publication, the respect of the rights and freedoms contained in the present Charter (...)."
} 
living conditions would be "understanding of primary health care" (art 11 para 2.e), which is of great importance given the threat of epidemics and viral infections in the continent (yellow fever, malaria, Ebola, HIV, or the COVID-19 pandemic).

The wording of the ACC, however, does not aim so much at raising awareness of the own human rights as it does at fostering respect for human rights. Both aims (raising awareness and fostering respect) are not completely diverse, but the second might seem more ambitious. Moreover, from a political perspective, democracy is enhanced if citizens are more and better educated, and in particular with regard to human rights. Education on human rights and democracy (more commonly "Human Rights Education") thus appears as a highly valuable resource. To be sure, the ACHPR has long been aware of its importance, as it showed with its Resolution on Human and Peoples' Rights Education ${ }^{62}$ of 1993 and other statements. ${ }^{63}$ The Member States of the African Union have, for their part, displayed a clear interest in promoting this kind of education, as the African Charter on Democracy, Elections, and Governance demonstrates. According to this instrument,

State Parties undertake to implement programs and carry out activities designed to promote democratic principles and practices as well as consolidate a culture of democracy and peace.

To this end, State Parties shall:

\section{(...) 4. Integrate civic education in their educational curricula and develop appropriate programs and activities. ${ }^{64}$}

The importance of this obligation is further underlined by another provision. Indeed, civic education shall be "systematic and comprehensive" and, more importantly, it shall aim "to encourage full participation of social groups with special needs in democracy and development processes". 65

These provisions of the ACDEG allow for three considerations.

Firstly, education is considered essential for the political participation of social groups (in this case, specifically those with special needs). Once again, the idea of education as empowerment, now applied to groups with special needs. Thus, the educational aim of fostering respect for human rights appears linked with the value of solidarity within society.

Secondly, the reference to "(social) groups" reminds of the abovementioned "intermediate bodies." Among these, political parties are of particular importance in a parliamentary democracy. Political parties, however, would be hardly democratic if their militants were unable to grasp the significance - and debate on the substance — of complex decisions advanced by their leaders. In a presidential democracy, the political

\footnotetext{
${ }^{62}$ Resolution on Human and Peoples' Rights Education, adopted by the ACHPR at its 14th Session, December 1993. The text is available at https:/www.ohchr.org/EN/Issues/Education/Training/Compilation/Pages/5 ResolutiononHumanRightsEducation(1993).aspx.

${ }^{63}$ In its 35th activity report, of 2013, the ACHPR highlighted "Lesotho's (...) new curriculum for schools which includes components of human rights issues affecting children."

${ }^{64}$ ACDEG, art 12. Emphasis added.

${ }^{65}$ ACDEG, art 31 para 2.
} 
party does not necessarily enjoy the same significance, but the education of those called to vote (especially a pluralistic and non-indoctrinating human rights education) remains of paramount importance. According to experts, "political representation means choosing, electing representatives, selecting the political class" (Bonfiglio 2013, 90; similarly, Randall 2007, 85-86), which confirms the importance of education as a crucial element for democracy. However, historically, in African politics, this has not excluded the possibility that the power of granting educational opportunities (e.g., through scholarships) was used, conversely, as an "enormously effective instrument of oneparty consolidation" (Coleman and Rosberg 1964, 666) or, more brutally, that teachers and health workers "were forced to attend political education meetings" under Mugabe's rule in Zimbabwe (Laakso 2007, 243). This confirms how strongly education can affect the political system.

Thirdly, the African conception of civic education appears in close connection with that of "development." If the notion of development may come as a novelty when discussing educational values, other principles deeply connected with it have been present in African human rights instruments since its early days. The ideas of independence, decolonization, and the highly interesting principle of African solidarity have more recently led to an emphasis on economic and social development. This, however, should not be deemed incompatible with the preservation of traditional values, territorial integrity, and African unity, as will be discussed below ("African Morals, Traditional Values and Cultures, and Other Specific Political Principles”).

\section{Preparation for Responsible Life in a Free Society in the Spirit of Understanding Among All Peoples}

Despite the strong connection of this principle with the full development of the personality, the authors of the African Child Charter have chosen to present it as a different goal. This principle is closely linked with the "universal" political aims of the core international human rights instruments as well. ${ }^{66}$ Nevertheless, the preparation for responsible life in freedom does not only apply to children, but also to adults, and, importantly, even to those incarcerated. ${ }^{67}$

Let us turn to the wording of the ACC. Its art 11 para 2 provides the following:

The education of the child shall be directed to:

(...) (d) the preparation of the child for responsible life in a free society, in the spirit of understanding, tolerance, dialogue, mutual respect and friendship among all peoples, ethnic, tribal and religious groups.

While the general drafting and many of the elements appear very close, or even identical, to the relevant paragraph of the CRC's, ${ }^{68}$ some differences should be underlined. The African wording thus features some new elements but, strangely enough, others have been erased. Among the latter, "in the spirit of" the CRC appeared

\footnotetext{
${ }^{66}$ See above "Promoting understanding, tolerance and peace."

${ }^{67}$ ACHPR, 31st activity report (of 2011), para 30.

${ }^{68} \mathrm{CRC}$, art 29 para 1.d. See above "Full Development of the Human Personality and Best Interest of the Child".
} 
the references to "peace," "equality of sexes," "friendship among all (...) national groups," and "persons of indigenous origin". The removal of the reference to national groups may be explained by the introduction, instead, of two new and more elaborate paragraphs on the matter (namely, $e$ and $f$ ). However, the reasons behind the other three suppressions appear obscure, and the result, difficult to approve.

The additions, nevertheless, enrich the text of the provision with some aspects of African legal and political thinking. Perhaps the most evident would be the reference to "tribal" groups as a basic organizational form of many African societies, a notion criticized for the "lack of conceptual groundwork and empirical testing" on whether and how ethnicity affects voting preferences (Elischer 2013, 25). Moreover, the ideas of "dialog" and "mutual respect" are also an important part of African culture, as the traditional notion of ubuntu expresses well (Venter 2004, 149 and Le Roux 2000, 43). As Vervliet (2009, 64) has written, "In (...) ubuntu, the human person does not stand on his own, but becomes more human in relation with other people".

Lastly, the reference to the "peoples" is not an innovation of the African instrument, but it certainly acquires a new significance given the importance of this notion in the continent's legal tradition of human rights. It should be noted that the African Charter, the ACHPR, and the African Court on Human and Peoples' Rights all bear the reference to the peoples in their very names, thus showing their importance as a subject of rights. Human and peoples' rights thus appear closely connected in the African conception. Unfortunately, the study of collective rights would require an in-depth approach that clearly exceeds the scope of this article.

\section{African Morals, Traditional Values and Cultures, and Other Specific Political Principles}

The UN Convention on the Rights of the Child referred to the development of respect for the child's "own cultural identity, language and values, for the national values of the country in which the child is living, the country from which he or she may originate, and for civilizations different from his or her own". Receptive to the influence of its immediate UN precedent, the African Child Charter picked up the baton and included four different provisions that expand these ideas.

The relevant parts of art 11 para 2 mandate the following:

The education of the child shall be directed to:

(...) (c) the preservation and strengthening of positive African morals, traditional values and cultures;

(...) (e) the preservation of national independence and territorial integrity;

(f) the promotion and achievement of African Unity and Solidarity;

Article 12, in turn, further elaborates on the right to culture:

State Parties shall respect and promote the right of the child to fully participate in cultural and artistic life and shall encourage the provision of appropriate and equal opportunities for cultural, artistic, recreational and leisure activity. 
Firstly, from the perspective of moral education, the ACC is unorthodox but honest when it accepts that not all African morals, traditional values, and cultures are necessarily "positive" and hence deserve to be promoted. Among the positive aspects, the abovementioned notion of ubuntu requires a socially valuable orientation of individual rights. In their definition of the African child, Nthontho and Ogina (2020) highlight the collective effort behind the education of the young. They illustrate this cultural pattern with the traditional saying that "it takes a village to raise a child". This communalist approach to human rights and education is genuinely African and is not to be found - at least not with the same intensity - in other conceptions. ${ }^{69}$ Another example of traditional values inspiring human rights can be found in the South African Constitutional Court's ruling on the Khosa case. ${ }^{70}$ According to Kamga $(2018$, 641), when the Constitutional Court held that "everyone's right to access social security encompasses permanent residents in the country" (including children), it was inspired by the values of ubuntu. On the other hand, a more negative aspect would be the use of corporal punishment. While it was banned by the South African Schools Act in 1996, this ban was subsequently challenged by 196 independent Christian schools. The Constitutional Court, however, upheld the Act in a memorable ruling by Justice Albi Sachs. ${ }^{71}$

By limiting its advocacy to the positive inheritance, the ACC separates itself from the wording of the older African Charter, which did not include any differentiation but rather mandated the protection of any "morals and traditional values recognized by the Community." Still, despite the more advanced contents of the ACC in this regard, basing on the African Charter may include some advantages, too. An important one concerns the possibility of using the rather open communications procedure of article 55 , thus attracting the attention of the ACHPR and, perhaps, driving it to use its "good offices" in search of a friendly settlement, or a recommendation, or even to submit the case to the African Court. ${ }^{72}$

In this regard, certain complaints have been addressed to the ACHPR despite the strict wording of its article 25 ("Every individual shall have the right to education"). Among these, for example, a case of 2003 concerning Cameroon reflected an attempt by the complainants to demonstrate a linguistic, cultural, and educational undermining of the Anglophone parts of the country by the government, thus trying to push the ACHPR to ponder on the argument of respect for cultural specificity and the protection of linguistic minorities. The ACHPR, nevertheless, rejected the complaint on article 17 due to lack of sufficient proof ${ }^{73}$ (but accepted several others, including certain forms of discrimination such as that of the English language in business transactions ${ }^{74}$ ).

The notion of culture, in the second place, is not only destined to the stationary status of preservation. The use of the term strengthening in art 11 para 2.c and especially that of participation (linked in article 12 with artistic and with recreational

\footnotetext{
${ }^{69}$ See above "The Importance of International Human Rights Law: Contestations and Reasons" and Stoppioni (2020, 2).

${ }^{70}$ Khosa v Minister of Social Development 2004 (6) SA 505 (CC) (Justice Mokgoro).

${ }^{71}$ Christian Education South Africa v Minister of Education (CCT4/00) [2000] ZACC 11; 2000 (4) SA 757; 2000 (10) BCLR 1051 (18 August 2000).

72 Protocol to the African Charter on Human and Peoples' Rights on the Establishment of an African Court on Human and Peoples' Rights (adopted 9 June 1998, entered into force 25 January 2004) art 5.

${ }^{73}$ Case of Mgwanga Gunme v. Cameroon, Comm. 266/2003, 26th ACHPR AAR Annex (Dec 2008-May 2009), see paras 145-150.

74 Ibid para 108.
} 
and leisure activities) bring the educational treatment of culture closer to its dynamic essence. Education should help the children to understand and preserve their cultural heritage but also to enjoy and develop it. The African Charter confirms this interpretation when it includes the right to "freely" "take part in the cultural life of his community" next to the very recognition of the right to education. ${ }^{75}$

Thirdly, the references to "national independence," "territorial integrity," "African Unity," and "African Solidarity" are of a more political nature and reflect the historical circumstances to which the rise of the human rights movement in Africa was bound. Indeed, all of these ideas seem in line with the basic orientations of the Organization of African Unity since its inception. It should be interesting to remind that in 1963, the African heads of states and governments declared themselves "Determined to safeguard and consolidate the hard-won independence as well as the sovereignty and territorial integrity of our states, and to fight against neo-colonialism in all its forms". ${ }^{76}$

A purpose later reinforced in the Preamble of the very African Charter on Human and People's Rights, where the member states of the OAU again showed themselves

Conscious of their duty to achieve the total liberation of Africa, the peoples of which are still struggling for their dignity and genuine independence, and undertaking to eliminate colonialism, neo-colonialism, apartheid, zionism and to dismantle aggressive foreign military bases and all forms of discrimination, particularly those based on race, ethnic group, color, sex, language, religion or political opinions.

Summarizing, the protection of African cultural values in human rights' instruments reveals the struggle of the continent to become politically independent and economically developed while (dynamically) preserving the best of its traditional identity.

\section{Respect for the Environment and Natural Resources}

\section{One last aim of education according to the African Child Charter concerns}

the development of respect for the environment and natural resources. ${ }^{77}$

Once again, the ACC takes up the baton of the UN Convention on the Rights of the Child, until then the only UN instrument on human rights to have mentioned environmental awareness as an educational value. Given the rich resources of the African continent, also from an economic perspective, the African instrument expands the scope in order to instill respect for natural resources as well. Indeed, natural resources have historically been over-exploited, either by colonial powers ${ }^{78}$ or under self-rule. The latter, nevertheless, were often responsible for some of the first conservation efforts as well (Van Eeden 2014, 640).

\footnotetext{
${ }_{75}$ African Charter art 17 para 2.

${ }^{76}$ Organization of African Unity Charter, 25 May 1963, (OAU Charter) Preamble.

${ }^{77}$ ACC art 11 para 2.g.

${ }^{78}$ C.W. de Kiewiet $(1941,188)$, in his History of South Africa, wrote that "In all the great colonial regions of the world the history of the ruthless exploitation of natural resources is a full one."
} 
This provision, therefore, points to the aim of delivering the continent from economic exploitation. In doing so, it is perfectly coherent with the African Charter's proud declarations that "All peoples shall freely dispose of their wealth and natural resources. This right shall be exercised in the exclusive interest of the people. In no case shall a people be deprived of it."79

Some of the most infamous cases of recent history are closely linked with this defense of the environment against large transnational companies backed by some governments. The most notorious is probably the Niger Delta dispute, ${ }^{80}$ but the aforementioned ACHPR/Kenya case concerning the rights of the Ogiek Community of the Mau forest is a more recent example.

\section{Final Considerations}

Both UN and regional systems reflect certain humanistic values that, despite different wordings and circumstances, may be considered essentially common to all three conceptions. Perhaps the best example is the principle of the full development of the personality (often linked with the child's best interest doctrine), but clearly not the only one. The promotion of understanding, tolerance, and of specific cultural values is also present in every human rights system. On the darker side, the risk of cultural indoctrination has made its appearance in both the European and the African contexts.

Despite these common aspects, regional systems also reveal specific conceptions that are due to each continent's own history and current challenges.

In the African system, the different Charters reflect a rather open understanding of cultural values and traditions by granting every individual the right to "freely participate" in cultural life. The historical struggle for political independence, economic development, and environmental protection has also left its mark on educational values. Concerning the enforcement of the Charters, however, the communications procedure before the ACHPR may only lead to the adoption of decisions that are technically not binding for the States Parties involved. This lack of binding force when discussing individual communications may explain why certain statements throughout the ACHPR's periodical activity reports have adopted a strongly critical style, for example with regard to access to education for pregnant girls. A more frequent intervention of the African Court might be desirable, but both the institutional framework and the system's budget entail limitations.

The ECtHR, on the other hand, may seem less demanding than the ACHPR in its requirements to States Parties. Examples of this are the frequent recourse to the margin of appreciation doctrine and the ECtHR's acquiescence to France's broad interpretation of secularism or Italy's defense of the crucifix as a symbol of universal values. However, this acquiescence in matters that are highly controversial within certain societies could paradoxically reflect a stronger institutional system and hence a smaller need to react to all challenges. This institutional strength (at least when compared to other human rights systems) arises from the solid position of the ECtHR as the only international protector of the ECHR and from the mandatory nature of its rulings for the

\footnotetext{
${ }^{79}$ African Charter art 21 para 1.

${ }^{80}$ Soc. and Econ. Rights Action Ctr. v. Nig, Comm. 155/96, 15th ACHPR AAR Annex V (2000-2001).
} 
States Parties involved. Nevertheless, and most importantly, the ECtHR receives and adjudicates a far larger number of cases than any other human rights system. This grants the European Court the opportunity to rule on each case considering the social, political, and legal specificity of the state concerned, rather than motivated by the need to develop a notion that is valid for the whole continent. It therefore seems to have more occasions to develop a nuanced body of principles. Such a system, however, requires greater funding by States Parties.

Acknowledgments The author wishes to kindly thank Prof Johan Beckmann, Prof Everard Weber and Dr. André du Plessis, from the University of Pretoria's Department of Education Management \& Policy Studies. This research was made possible by the University of Pretoria's Visiting Professors Program.

\section{Compliance with Ethical Standards}

Conflict of Interest The author declares that he has no conflict of interest.

\section{References}

Alfredsson G (2001) The Right to Human Rights Education. In: Eide A, Krause C, Rosas A (eds) Economic, Social and Cultural Rights, 2nd Nijhoff, Leiden, pp 273-288

Benedek W (2007) Human Rights Education. In: Wolfrum R, Lachenmann F et al (eds) Max Planck Encyclopedia of Public International Law. OUP, Oxford. Also at https://static.uni-graz. at/fileadmin/rewi-zentren/uni-etc/Nr. 9 benedek hre.pdf. Accessed 14 Feb 2020

Bonfiglio S (2013) I partiti e la democrazia. Il Mulino, Bologna

Bonfiglio S (2018) Intercultural Constitutionalism: From Human Rights Colonialism to a New Constitutional Theory of Fundamental Rights. Routledge, London

Botha J (2019) In search of ways of curtailing aggression and violence in schools: A human rights-based approach. In Rossouw JP, De Waal E (eds) Human Rights in Diverse Education Contexts. Aosis, Cape Town, pp 173-193

Bourdieu P, Passeron JC (1970) La Reproduction. Éléments pour une théorie du système d'enseignement. Minuit, Paris. English version (1990) as Reproduction in Education, Society and Culture. Sage, London

Coleman JS, Rosberg CJ (1964) Conclusions. In: JS Coleman, CJ Rosberg (eds) Political parties and national integration in tropical Africa. University of California Press, Berkeley, 655-691

De Kiewiet CW (1941) A History of South Africa - Social \& Economic. Oxford University Press, London

Dewey J (1916, reprint 2015) Democracy and education. Forgotten Books, London

Du Plessis A (2019) School governance and management decentralisation and school autonomy in the South African education system. Dissertation, North-West University

Du Plessis A (2020) The Emergence of Decentralised-centralism in the South African Education Governance System. J S Afr Stud 46.1:165-183. https://doi.org/10.1080/03057070.2020.1705618

Elischer S (2013) Political Parties in Africa. Ethnicity and Party Formation. Cambridge University Press, Cambridge

García Guerrero JL (2014) La publicidad. Fundamentos y límites constitucionales. Tirant lo Blanch, Valencia Glenn CL (2017) What is at stake in debates over education and religion. In: Meix Cereceda P, De Groof J (eds) Religious and ideological rights in education. Judicial perspectives from 32 legal systems. Wolf, Nijmegen, pp 29-82

Häberle P (1981) Verfassungsprinzipien als Erziehungsziele. In: Eichenberger K, Recht als Prozess und Gefüge. Festschrift für Hans Huber zum 80. Geburtstag. Stämpfli, Bern, pp 211-239

Häberle P (2004) Die Menschenwürde als Grundlage der staatlichen Gemeinschaft. In: Isensee J, Kirchhof P (eds) Handbuch des Staatsrechts vol. 2. Müller, Heidelberg, pp 319-367

Hevia Rivas R (2008) Pobreza y derecho a la educación. Revista IIDH 48:135-153

Hevia Rivas R (2010) El Derecho a la Educación y la Educación en Derechos Humanos en el contexto internacional. Revista Latinoamericana de Educación Inclusiva 4.2:25-39. http://rinace. net/rlei/numeros/vol4-num2/art1.html. Accessed 19 Feb 2020 
Jonsson JO (2016) Education, Social Mobility and Social Reproduction in Sweden: Patterns and Changes. Int J Sociol 23(1):2-30

Kamga SD (2018) Cultural values as a source of law: Emerging trends of ubuntu jurisprudence in South Africa. African Human Rights Law Journal, 18.2:625-649

Laakso L (2007) Insights into Electoral Violence in Africa. In: Basedau M, Erdmann G, Mehler A (eds) Votes, Money and Violence. Political Parties and Elections in Subsaharan Africa. Nordiska Afrikainstitutet and University of Kwazulu-Natal, Stockholm and Scottsville, pp 224-252

Le Roux J (2000) The concept of 'Ubuntu': Africa's most important contribution to multicultural education?. Multicultural Teaching 18.2:43-46

Lenski G (1966) Power and privilege. A theory of social stratification. McGraw Hill, New York

Martín Criado E (2010) La escuela sin funciones. Bellaterra, Barcelona

Mittler P (2000) Working Towards Inclusive Education. Social Contexts. David Fulton, New York

Mokgoro Y (1998) Ubuntu and the Law in South Africa. Potchefstrom Electronic Law Journal, 1.1:1-11

Nthontho M, Ogina T (2020) Conceptualisation of an "African Child" in the context of basic education in South Africa. Journal of Education - South African Education Research Association (forthcoming)

Randall V (2007) Political Parties in Africa and the Representation of Social Groups, In: Basedau M, Erdmann G, Mehler A (eds) Votes, Money and Violence. Political Parties and Elections in Subsaharan Africa. Nordiska Afrikainstitutet and University of Kwazulu-Natal, Stockholm and Scottsville, pp 82-104

Solozábal Echavarría JJ (1994) Dignidad de la persona. In: Montoya Melgar A (ed) Enciclopedia Jurídica Básica. Civitas, Madrid, p 2489

Stoppioni E (2020) Some reflections on the human rights discourse in the EU-Japan strategic partnership agreement. E-Conference on EU-Japan Relations, BlogDroitEuropeen.com 1-5

Udombana NJ (2006) Social Rights Are Human Rights: Actualizing the Rights to Work and Social Security in Africa. Cornell International Law Journal 39.2:181-242

Van Eeden ES (2014) An environmental history of South Africa. In Pretorius FJ (ed) A History of South Africa. From the Distant Past to the Present Day. Protea, Pretoria, pp 633-663

Venter E (2004) The Notion of Ubuntu and Communalism in African Educational Discourse. Studies in Philosophy and Education 43.2-3:149-160

Vervliet C (2009) The Human Person. African Ubuntu And The Dialogue Of Civilisations. Adonis \& Abbey, London

White ND (1997) Keeping the peace. The United Nations and the maintenance of international peace and security. 2nd Manchester University Press, Manchester

Žižek S (2005) Against Human Rights. New Left Review 34

Publisher's Note Springer Nature remains neutral with regard to jurisdictional claims in published maps and institutional affiliations. 